\title{
Determinants of Stock-Out in Retail Shops in Ghana: Evidence from Kumasi Metropolis
}

\author{
Charles Adusei ${ }^{1}$, Dadson Awunyo-Vitor ${ }^{2 *}$ \\ ${ }^{1}$ Department of Accounting and Finance, School of Business, Garden City University College, Kumasi, Ghana \\ ${ }^{2}$ Department of Agricultural Economics, Agribusiness and Extension, Faculty of Agriculture, College of \\ Agriculture and Natural Resources, Kwame Nkrumah University of Science and Technology, Kumasi, Ghana \\ Email: *Awunyovitor@yahoo.co.uk
}

Received 20 October 2014; revised 25 November 2014; accepted 10 December 2014

Copyright (C) 2014 by authors and Scientific Research Publishing Inc.

This work is licensed under the Creative Commons Attribution International License (CC BY). http://creativecommons.org/licenses/by/4.0/

\section{Abstract}

This study investigates factors influencing stock-out occurrence in retail shops in Kumasi Metropolis in Ghana. The study sampled two hundred and forty four retail outlets located in the central business areas of Kumasi Metropolis. A well structured questionnaire was used to solicit information from the respondents. Both descriptive statistics and inferential statistics were used to analyse the data. The results of the study revealed that delay in supplier's items, demand underestimation, and bad back-of-store practices were the main causes of stock-outs. Generally, the study reveals that most retailers are not equipped to use most of the sophisticated stock control techniques and only limit themselves to the use of stock books to control stock. Information and communication technology and collaboration with suppliers were considered by the retailers as the main stock control implementation barriers. The study concludes that, although retailers are aware of the occurrence and the causes of stock-outs, many of them had done little to put in place measures to control it; and even the few that have been able to put in place stock control measures were confronted with implementation challenges. It is therefore recommended that retailers should adopt effective and efficient stock control techniques to limit out-of-stock occurrence.

\section{Keywords}

Retail Shops, Stock-Out, Kumasi Metropolis, Ghana, Logit

\section{Introduction}

Retailing includes the business activities involved in selling goods and services to consumers for their personal, family, or household use. It includes every sale to the final consumer. Berman and Evans [1] indicate that there

\footnotetext{
*Corresponding author.
} 
are three key issues that retailers must resolve: How best they can serve their customers while earning a fair profit; how they can stand out in a highly competitive environment where consumers have so many choices; and how they can grow their businesses while retaining a core of loyal customers.

In a highly competitive retail industry, the occurrence of stock-out or out-of-stock (OOS) is an important issue confronting retailers. Its occurrence is a common phenomenon among frequently purchased product categories [2]. Retailers are therefore faced with the challenge of keeping products that customers want and need in stock. According to Battista et al. [3], out-of-stock (OOS) has a significantly negative effect on a company's revenue, yet many companies have done little to quantify this phenomenon and the relative lost sales.

Many authors have stressed that the OOS phenomenon in retail stores is the direct symptom of the failure of some supply processes, such as incorrect estimation of demand, inefficient distribution of products between different stores, incorrect replacement criteria, etc. [3]. In the greater part of retail business the only available information pertaining to customer demand derives from sales data: When a product is out-of-stock then, there is usually no awareness of the entity of the potential lost sales. This generates a problem in demand forecasting, which should be the starting point for all operations planning, and plays a key role in supporting the achievement of a company's strategic targets [4].

Empirical evidence suggest that stock-out in the retailing industry is common: Vasconcellos [5] estimates the stock-out rates in retail stores have consistently averaged above 8 percent; the rates reported from Peckham [6] to Gruen et al. [7] are reasonably similar. For instance, a study of product availability in US supermarkets found out that $8.2 \%$ of items, on average, were unavailable to the consumer on a typical afternoon in eight categories examined [8]. Further, according to Emmelhainz et al. [9], "retailers lose up to $14 \%$ of customers due to product out-of-stock where as a brand manufacturer may lose more than 50\%".

A rise in purchasing power and a shift towards formal retail space is helping to burnish a positive outlook for retailers in Ghana. Mall retailing is still in its infancy, particularly outside the capital, but international brands and developers are increasingly enthusiastic about the country [10]. At present, however, modern retail accounts for only around $5 \%-10 \%$ of sales volumes [10]. Despite the little strides made by the retail industry in Ghana, there is a vast gap in the body of literature regarding the phenomenon of stock-outs. In contrast to the situation in Ghana, international literature is rich in studies along two main lines: reducing the number of stock-outs instances; and offering remedies to manage the consumer responses whenever stock-out situations is unavoidable or is too expensive to eliminate [11] [12]. Studies of this nature are of great importance not only to retailers, but also manufacturers. Gruen and Corsten [13] said "in $45 \%$ of the stock out cases the consumers substitute their items, in around $31 \%$ of the cases they change stores, and in $14 \%$ of the cases they rarely return". Hence "stockouts" is and will continue to be an important managerial problem.

The effects of stock-outs go beyond the lost sales of the item in question. According to Gruen and Corsten [13], "a variety of strategic and operational costs apply to both retailers and suppliers including decreases in store and brand equity and attenuated impact of promotions and trade promotion funds". Stock-outs distort demand and leads to inaccurate forecast. Also, during stock-outs situations employees spend considerable time trying to satisfy customers who enquire about OOS items. OOS also have cost implications for customers because the amount of time spent during shopping could be spent productively elsewhere [13].

Despite innovations such as EDI (Electronic Data Interchange) and JIT (Just-in-time) systems that attempt to improve the supply chain between manufacturers and retailers, stock-outs situations still occur [14]. This is as a result of the increasing number of retail items flooding the markets consequently reducing the storage capacity per item on shelves or in storerooms. This reduction has also coincided with a decrease in storeroom areas by many retailers who want to expand selling space, and to keep inventory cost down. These developing trend means that there is a high risk of stock-outs.

Even though the importance of this problem cannot be over emphasize, studies on stock-outs come in handy and are mainly focused on understanding consumer reactions to stock-outs, with little research looking into the causes and methods to mitigate it.

The purpose of this study is to investigate factors influencing stock-out in retail shops in Kumasi Metropolis in Ghana.

\section{Literature Review}

\subsection{Stock Management-Theoretical Review}

Inventory management is the "process of efficiently overseeing the constant flow of units into and out of an ex- 
isting inventory" [15]. According to Toomey [15], "inventory management primarily reflects the act of specifying the size and placement of stocked goods". The process (inventory management) is required at different locations within a facility or within multiple locations of a supply network. Generally, "the aim is to protect the regular and planned course of production against the random disturbance of running out of materials or goods" [15].

Thus, effective inventory management "is all about knowing what is on hand, where it is in use, and how much finished product results" [16]. It points out that "this process usually involves controlling the transfer in of units in order to prevent the inventory from becoming too high or dwindling to levels that could put the operation of the company into jeopardy". Competent inventory management "also seeks to control the costs associated with the inventory, both from the perspective of the total value of the goods included and the tax burden generated by the cumulative value of the inventory” [16].

As part of its logistics efforts, a retailer employs inventory management to acquire and maintain a proper merchandise assortment while ordering, shipping, handling, storing, displaying, and selling costs are kept in check. The scope of inventory management "also concerns the fine lines between replenishment lead time, carrying costs of inventory, asset management, inventory forecasting, inventory valuation, inventory visibility, future inventory price forecasting, physical inventory, available physical space for inventory, quality management, replenishment, returns and defective goods and demand forecasting and also by replenishment or can be defined as the left out stock of any item used in an organization” [17].

It has been argued that "balancing the various tasks of inventory management means paying attention to three key aspects of any inventory”. Generally, the first aspect primarily concerns time. "In terms of materials acquired for inclusion in the total inventory, this means understanding how long it takes for a supplier to process an order and execute a delivery". Inventory management also demands that a "solid understanding of how long it will take for those materials to transfer out of the inventory be established” [17]. Knowing these two important lead times "makes it possible to know when to place an order and how many units must be ordered to keep production running smoothly” [18].

Calculating what is known as buffer stock is "also key to effective inventory management. Essentially, buffer stock is additional units above and beyond the minimum number required to maintain production levels” [17]. For example, the "manager may determine that it would be a good idea to keep one or two extra units of a given machine part on hand, just in case an emergency situation arises or one of the units proves to be defective once installed”. According to Toomey [15], "creating this cushion or buffer helps to minimize the chance for production to be interrupted due to a lack of essential parts in the operation supply inventory”.

Inventory management "is not limited to documenting the delivery of raw materials and the movement of those materials into operational process” [15]. The movement of those materials as they go through the various stages of the operation is also important. "Typically known as a goods or work in progress inventory, tracking materials as they are used to create finished goods also helps to identify the need to adjust ordering amounts before the raw materials inventory gets dangerously low or is inflated to an unfavorable level” [16].

Finally, "inventory management has to do with keeping accurate records of finished goods that are ready for shipment" [12]. This often means "posting the production of newly completed goods to the inventory totals as well as subtracting the most recent shipments of finished goods to buyers". "When the company has a return policy in place, there is usually a sub-category contained in the finished goods inventory to account for any returned goods that are reclassified as refurbished or second grade quality” [8]. Accurately maintaining figures on the finished goods inventory "makes it possible to quickly convey information to sales personnel as to what is available and ready for shipment at any given time” [9].

Corsten and Gruen [8], again add that "in addition to maintaining control of the volume and movement of various inventories, inventory management also makes it possible to prepare accurate records that are used for accessing any taxes due on each inventory type". Thus the absence of "precise data regarding unit volumes within each phase of the overall operation, the company cannot accurately calculate the tax amounts” [9]. This could lead to underpaying the taxes due and possibly incurring stiff penalties in the event of an independent audit.

Berman and Evans [1] argue that having a proper inventory on hand is a difficult act, they went on to say that the situation is more complicated for retailers that carry fad merchandise, that handle new items for which there is no track record, and that operate in new business formats where demand estimates are often inaccurate. Thus, inventory levels must be planned in relation to the products involved: staples, assortment merchandise, fashion 
merchandise, fads, and best-sellers.

\subsection{Inventory or Stock Management-Empirical Review}

A stock-out event occurs where inventories get exhausted. "While out-of-stocks can occur along the entire supply chain, the most visible kind are retail out-of-stocks in the fast moving consumer goods industry (e.g., sweets, diapers, fruits)" [9]. The Business Dictionary defines stock-out as "a situation in which the demand or requirement for an item cannot be fulfilled from the current inventory".

Ehrenthal et al. [9] simply puts the definition of stock-out as "the situation where the demand for an inventory item outpaces your supply and the need for the item cannot be fulfilled". According to them stock-outs can seriously affect the operations of an organisation if the necessary measures are not instituted. Further, they also explain a stock-out as the situation when inventory gets depleted and the organisation cannot immediately obtain it from its suppliers.

Stock-out is also defined by Vasconcellos and Sampaio [5] as "a situation where an item that is regularly commercialized at a point of sale and occupies a specific place on the shelves is not available to the consumer in the store at the moment of purchase". One of the characteristics of a stock-out is "an inefficient process of refilling shelves" [5]. According to Vasconcellos and Sampaio [5], "a stock-out rate is the percentage of all the items commercialized that should be for sale, but are not found on the shelves". For example, "a $10 \%$ rate of stockouts as referring to 500 out of 5000 items catalogued and commercialized by a supermarket that would not be available on the shelves for immediate purchase by the final consumer" [5].

According to Berger, "retail stock-outs problems have been studied from two major perspectives: Measurement of stock-outs rates in stores and consumer response to stock-outs". Zinn and Liu have suggested that "regardless of the perspective guiding the research, most studies suggest that managers deal with stock-outs by taking action to reduce the number of stock-outs as much as possible” [19]-[21].

Gruen and Corsten [8] quote $8.3 \%$ as the global average of retail out-of-stocks. Their explanation to this average is that "shoppers will have a $42 \%$ chance of fulfilling a ten-item shopping list without encountering a stockout". According to Aastrup and Kotzab [22], "the several initiatives aimed at improving the collaboration of retailers and their suppliers, such as Efficient Consumer Response (ECR), coupled with the increasing use of new technologies such as radio-frequency identification (RFID) and point-of-sales data analytics, it has translated into little improvements".

Corsten and Gruen [8] posit that "for a supplier or retailer, stock-outs are simply part and parcel of doing business - with hundreds, thousands or even hundreds of thousands of stock outs, it is unsurprising when a marginal few are unavailable; whilst it is a serious inconvenience to buyers". Failure on the part of retailers to address the problem will result in the loss of revenue and customer loyalty [8].

There are two potential consequences of stock-outs: "subject to distribution inventory stock-outs or manufacturing inventory stock-out, the impact on the supplier and the customer is different in terms of extent and scale, i.e. the impact is greater and more serious for one party than the other one" [8].

Corsten and Gruen [8] explain that "the attitude toward stock-out varies accordingly; if there is a manufacturing inventory stock-out in the manufacturing companies like Ford and Toyota, the result is critical—-the production line will be shut down and startup costs are very high". Thus such stock-out should be avoided. Corsten and Gruen [8], however, suggests that "in case of distribution inventory stock-outs, the impact on the customer is usually not big and serious, e.g. it is not a big deal when consumers encounter such a stock-out, therefore their counterparts-the suppliers, such as wholesalers and retailers, tolerate stock-outs”.

It has been argued that "when a supplier is unable to satisfy demand with available inventory, one of four events may occur: 1) The customer waits until the new replenishment arrives; 2) The customer back orders the product; 3) The sale is lost; 4) The customer is lost” [23].

Krafft and Mantrala [24] indicate that out-of-stock can have severe consequences for retailers. These severe consequences arise because consumers may exhibit a negative response to out-of-stocks. Out-of-stocks reactions can be classified into two clusters: (a) buying a substitute; and (b) not buying a substitute during the store visit. This classification is very interesting from a retailer's perspective. When a substitute is purchased the retailer will lose almost no sales. However, when a consumer decides not to buy a substitute in the same store, sales are lost.

Brand, item, and category should have no negative consequences for the retailer. In fact, a brand switch from a national brand to a private label may have positive profit consequences owing to higher private label margins. 
Of the "no-substitute” purchase reactions, store switch in particular has rather negative consequence for retailers. In the case of store switching, consumers visit another store to buy the product that is out of stock. In this competing store, consumers can also purchase products in other categories which they would normally have purchased in the store where the out-of-stock occurred.

According to Corsten and Gruen [8], while taking action to reduce the number of stock-outs is clearly an important component of stock-outs management, it is likely to be insufficient to solve the problem. The rates reported by Peckham [6] match Berger [20], "remaining around the level of 8.0\%, while other research published within this forty-year time span reported similar rates". Second, "the stock-outs problem is becoming more difficult to manage due to the continued trends of product proliferation, scrambled merchandising and shorter product life cycles” [20]. It points to the possibility of stock-out rates never heading to zero.

Consequently, Anderson et al. [11] have stated that "stock-outs should be managed with a combination of efforts to (1) reduce the number of stock-outs instances and (2) offer remedies to manage the consumer's response whenever the stock-outs is unavoidable or is too expensive to eliminate". "While international literature is rich in studies along these two lines, Brazilian literature lacks information about stock-outs in its market. The theme is a concern to both retailers and manufacturers who are equally interested in stock-outs problems” [12].

This implies that stock-out has consistently remained an important managerial problem.

Zinn and Liu [21] investigated the influence of other variables, such as "urgency in purchase of item, promotion, brand loyalty, surprise with stock-outs, pre-visit agenda and whether or not the consumer is upset with stock-outs". Sloot et al. [25], among other researchers, have identified a number of variables that "influenced the consumer's SDL (substitute, delay or leave) behavior”. According to Zinn and Liu [21], "situational variables such as urgency and level of planning (planned purchase or impulse purchase) greatly influence the consumer's decision”.

According to Bhargava et al. [12], "these findings took the theme of stock-outs to another level of analysis and generalization". The important thing here is "the variables that influence consumer behaviour in order to be able to help retail businesses discover new ways to minimize the number of consumers leaving the store and at least encourage the consumer to substitute the item or delay the purchase” [12].

\section{Methodology}

\subsection{Sources of Data}

The data for the study were predominantly primary data collected from traders who have registered with Kumasi Metropolitan Assembly (KMA) as businesses operating within the metropolis. In all the KMA offices have 1300 registered traders. The total sample size was estimated using an estimation method given by Yamane [26]:

$$
n=\frac{N}{1+N(e)^{2}}
$$

where

$n$ is the sample size;

$e=$ error level; $e=1$ - confidence level; and

$N$ is the total population of registered traders.

Assuming 95\% confidence level, $e=0.05$ and there are an estimated 1300 registered traders within the study area as provided by KMA officers, a sample size of 300 registered traders were selected for the study However, with a large population, Frankfort-Nachmias and Nachmias [27] proposed the use of a correction factor in determining optimal population size as follows:

$$
n^{\prime}=\frac{n}{1+n / N}
$$

where

$$
\begin{aligned}
& n^{\prime}=\text { optimal sample size; } \\
& N=\text { The total population to be surveyed }
\end{aligned}
$$

$$
n^{\prime}=\frac{300}{1+300 / 1300}=244
$$


$n$ = Sample size as determined above.

The total sample of 244 respondents was randomly selected for the study.

\subsection{Analytical Framework}

Descriptive statistics such as frequency tables and percentages were used to present the socio-economic characteristics of respondents and the type of retail businesses they owned. A Logit regression model was used to examine the factors influencing stock-out in these retail shops. The phenomena of retail shops experiencing stockout or not give a binary dependent variable which can be modeled using the above relationships:

$$
Y_{i}=\beta X_{i}+\mu_{i}
$$

where $Y_{i}$ is equal to one (1) when a respondent (shop owner) experience stock-out and zero (0) otherwise; this means: Equation (1) represents a binary choice model involving the estimation of the probability of respondents experiencing stock-out $(Y)$ as a function of independent variables $(X)$. Mathematically, this is represented as:

$$
\begin{gathered}
\operatorname{Prob}\left(Y_{i}=1\right)=F\left(\beta^{\prime} X_{i}\right) \\
\operatorname{Prob}\left(Y_{i}=0\right)=1-F\left(\beta^{\prime} X_{i}\right)
\end{gathered}
$$

where $Y_{i}$ is the observed response for the $i$ th observation of the response variable $Y$. This means that $Y_{i}=1$ for a shop owner who experiences stock-out and $Y_{i}=0$ for an owner who does not experience stock-out. $X_{i}$ is a set of independent variables which are expected to influence stock-out such as literacy, monthly income, age, marital status, gender, etc. associated with the ith individual, which determine the probability of experiencing stock-out $(P)$. The function $F$ may take the form of a normal, logistic or probability function. In this study a logit model was employed to examine the factors influencing stock-out in retail shops. The logit model uses a logistic cumulative distributive function to estimate $P$ as follows [28]:

$$
\begin{gathered}
P(Y=1)=P_{i}=\frac{e^{\beta^{\prime} X}}{1+e^{\prime} X} \\
P(Y=0)=1=P_{i}=1-\frac{e^{\beta^{\prime} X}}{1+e^{\beta^{\prime} X}}=\frac{1}{e^{\beta^{\prime} X}}= \\
Z=\beta^{\prime} X=\beta_{0}+\beta_{i} X_{i} \\
P_{i}=\frac{1}{1+e^{-Z}} \\
1-P_{i}=1-\frac{1}{1+e^{Z}} \\
\frac{P_{i}}{1-P_{i}}=\frac{1+e^{Z}}{1+e^{-Z}}
\end{gathered}
$$

Taking log we have Equation (10) as follows

$$
\ln \left(\frac{P_{i}}{1-P_{i}}\right)=\beta_{0}+\beta_{i} x_{i}
$$

The empirical model is specified as:

$$
\begin{aligned}
\ln \left(\frac{p}{1-p}\right)=Y= & \propto_{0}+\propto_{1} X_{1}+\propto_{2} X_{2}+\propto_{3} X_{3}+\propto_{4} X_{4}+\propto_{5} X_{5}+\propto_{6} X_{6}+\propto_{7} X_{7} \\
& +\propto_{8} X_{8}+\propto_{9} X_{9}+\propto_{10} X_{10}+\propto_{11} X_{11}+\propto_{12} X_{12}+\varepsilon
\end{aligned}
$$

\subsection{Variables Description}

Dependent variable: 
$Y=1$ if respondent experience stock-out, zero (0) otherwise.

Independent variable:

$X_{1}=$ Age of shop owner in years;

$X_{2}=$ Age of the business in years;

$X_{3}=$ Knowledge of stock management dummy ( 1 = Has knowledge; 0 = Otherwise);

$X_{4}=$ Daily sales of the trader;

$X_{5}=$ Gender of the business operator, dummy ( 1 = Male; 0 = Otherwise $)$;

$X_{6}=$ Number of years spent schooling;

$X_{7}=$ Distance to the nearest supplier office in kilometers;

$X_{8}=$ Ability to use ICT to order goods ( $1=$ If respondent has ability to use ICT; $0=$ Otherwise);

$X_{9}=$ Size of the business with net assets in Ghana Cedis;

$X_{10}=$ Number of employees;

$X_{11}=$ Take records of inflows and outflow of stock.

$\propto_{0}, \propto_{1}, \cdots, \propto_{11}$ are coefficients to be estimated and $\varepsilon$ is the error term which captures discrepancies due to human measurement and natural factors.

Kendall's Coefficient of Concordance $(W)$ analysis was used to rank the items identified as constraints to stock management by the respondents. The degree of agreement of the rankings by the respondents was then measured as $W$ which ranges from 0 to 1 . In deriving $W$, let $T$ represents the sum of ranks for each constraint being ranked by the respondents. The variance of the sum of ranks is given by:

$$
\operatorname{Var}_{T}=\frac{\sum T^{2}-\left(\sum T\right)^{2} / n}{n}
$$

where Var denotes variance and $n$ denotes the number of constraints. The maximum variance of $T$ is given by

$$
m^{2}\left(n^{2}-1\right) / 12
$$

where $m$ is the number of respondents. The formula for Kendall's coefficient of concordance $W$ is given by

$$
W=\frac{\left(\sum T-\left(\sum T\right)^{2} / n\right) / n}{m^{2} *\left(n^{2}-1\right) / 12}
$$

By simplifying Equation (3) above, the result in the computational formula for $W$ as:

$$
W=\frac{12\left[\sum T^{2}-\left(\sum T\right)^{2} / n\right]}{m n^{2}\left(n^{2}-1\right)}
$$

\section{Results and Discussion}

\subsection{Demographic Characteristics}

Table 1 presents the result of demographic and socioeconomic characteristics of the respondents. Genders of the respondents were evenly spread with $58 \%$ being males and $42 \%$ being females. This means that only $58 \%$ of the retail shops are owned by male hence the retail sector in Kumasi Metropolis is not dominated by one particular gender group.

The results of the study indicates that most of the respondents are within the 30 - 39 years age bracket (53\%), this is followed by 18 - 29 (20\%) while $16 \%$ of the respondents are within the age of 40 to 49 years. The rest are $5 \%$ and $6 \%$ respectively for ages between 50 and 59 years and 60 years above. Thus the majority of the shop owners in the retail sector are in their active ages. This might be due to the fact that the retail business is a very demanding job.

The results also indicate that all the respondents sampled for the study have some level of formal education. Forty-six percent of the respondents had completed Higher National Diploma (HND)/Diploma, 38.0\% had Senior High School education certificates; while 15\% of the respondent had first (Bachelor's) Degree and only 1 
Table 1. Frequency distribution of demographic characteristics.

\begin{tabular}{|c|c|c|c|}
\hline Items & Description & Frequency & Percentages \\
\hline \multirow[t]{2}{*}{ Gender } & Male & 142 & 58 \\
\hline & Female & 102 & 42 \\
\hline Total & & 244 & 100 \\
\hline \multirow[t]{5}{*}{ Age } & $18-29$ & 49 & 20 \\
\hline & $30-39$ & 129 & 53 \\
\hline & $40-49$ & 39 & 16 \\
\hline & $50-59$ & 12 & 5 \\
\hline & $>60$ & 15 & 6 \\
\hline Total & & 244 & 100 \\
\hline \multirow[t]{6}{*}{ Education } & JHS & 2 & 1 \\
\hline & SHS & 93 & 38 \\
\hline & HND & 112 & 46 \\
\hline & Bachelors' & 37 & 15 \\
\hline & Masters & 0 & 0 \\
\hline & $\mathrm{PhD}$ & 0 & 0 \\
\hline Total & & 244 & 100 \\
\hline \multirow[t]{4}{*}{ Experience } & 0 - 3 years & 163 & 67 \\
\hline & $4-6$ years & 56 & 23 \\
\hline & 7 - 10 years & 15 & 6 \\
\hline & $>10$ years & 10 & 4 \\
\hline Total & & 244 & 100 \\
\hline \multirow[t]{5}{*}{ Type of business } & Auto parts/Accessories & 37 & 15 \\
\hline & Office stationeries & 49 & 20 \\
\hline & Health and personal care & 61 & 25 \\
\hline & Electrical appliances & 20 & 8 \\
\hline & General merchants & 77 & 12 \\
\hline Total & & 244 & 100 \\
\hline
\end{tabular}

Source: Field Survey Data 2014.

person had a master's degree. The results means that the majority of the employees are SHS and Diploma/HND graduates: This can be attributed to the fact that most of the retail shops begin as family businesses.

Sixty-seven percent of the respondents had been operating their business for $0-3$ years, $23 \%$ had been in the retail business for 4 - 6 years, while 6\% had operated retail shops for 7 - 10 years, and only a few of them (representing 4\%) had been with an outlet for more than 10 years. This result supports the study which revealed that most SMEs fails within the first 1 - 10 years of its formation [29]. Table 1 also indicates that $25 \%$ of the respondents operate health/personal care shops while $25 \%$ owned auto parts/accessories, and $20 \%$ had office/stationery outlets. Electrical appliances and general merchants accounted for $8 \%$ and 32\% of the respondents respectively. The remaining few of the respondents are evenly spread among the other types of retail outlets. 


\subsection{Type of Sourcing and Supplier Frequency}

Respondents were asked to indicate the type of sourcing their outlet uses to stock their shops. The results, as presented in Table 2, shows that of the majority of the respondents (182), $75 \%$ of them are into multiple sourcing and $25 \%$ of the respondents relied on one supplier to supply them with products. This result is consistent with the findings of Christopher [30] which revealed that retail shops used multiple sourcing as they are not sure of the reliability of the suppliers.

Table 2 also indicates how frequently the retail outlets are supplied with items by their suppliers. The results indicated that $79 \%$ of the retail outlets get their supplies monthly, and $15 \%$ of the respondents stated that they had their supply on a weekly basis. The rest of the respondents (6\%) could not indicate a regular pattern. Due to demand uncertainties, and coupled with inaccurate forecasting by the shop owners, those who do not receive regular supply may experience stock-out.

\subsection{Determinants of Stock-Out}

One of the major objectives of the study is to identify the factors that influence stock-out in retail shops in the Kumasi Metropolis. The estimated logit regression model (Table 3) gave an adjusted Pseudo R-squared of about 0.71 and the log likelihood ratio (LR) statistic is significant at 1 percent. Given these two goodness of fit measures, it is concluded that the logit model used has integrity and is appropriate.

The result shows that 5 out of the 9 independent variables are statistically significant. Age is negative and significantly different from zero at $1 \%$. This means that the younger people have a greater probability of experiencing stock-out in their retail shop as compared with older people. However, the square of the age variable is positive and also significant at $1 \%$. This means that as retail shop owner advances in age the probability of stock-out reduces up to a point in age. This is economically plausible since the younger retail shop owners might also be in other businesses and may not have enough time to consistently check their stocks which may lead to stock-out. The marginal effect revealed that an addition year in age would decrease stock-out by $0.014 \%$.

The retail shop owner's knowledge in stock management was also assessed using a dummy variable. The coefficient of this variable is negative and significant. This implies that those who have knowledge in stock management are less likely to experience stock-out. The marginal effect is 0.40 which implies that those retail shop owners who have knowledge in stock management are $40 \%$ less likely to experience stock-out.

Gender in the model was a dummy where one represents the male category. From the results, the variable is significant and positive. This means that the male has a greater probability of experiencing stock-out as compared to their female counterparts. This meets the research a priori expectation since the male appear to be involved with a lot of activities and do not have much time to be taking stock regularly as compared to female in the retail businesses. This is in line with the findings of Campo et al., [31] who also found that females have a lower probability of experiencing stock-out. The marginal effect revealed that female retail shop owners are 30\% less likely to experience stock-out. Marital status was specified as a dummy variable. This variable exhibits negative significant coefficient value which implies that married people have a lower probability of experiencing stock-out. This may be attributed to the fact that they may have a wife who would be able to take stock. In fact

Table 2. Type of sourcing and supply frequency.

\begin{tabular}{|c|c|c|c|}
\hline Items & Description & Frequency & Percentage \\
\hline \multirow[t]{2}{*}{ Type of sourcing } & Single & 62 & 25 \\
\hline & Multiple & 182 & 75 \\
\hline Total & & 244 & 100 \\
\hline \multirow[t]{3}{*}{ Supply frequency } & Monthly & 192 & 79 \\
\hline & Weekly & 37 & 15 \\
\hline & Random & 15 & 6 \\
\hline Total & & 244 & 100 \\
\hline
\end{tabular}

Source: Field Survey Data 2014. 
Table 3. Logit regression results of determinants of stock-out in retail shops.

\begin{tabular}{|c|c|c|c|}
\hline Independent variables & $\begin{array}{l}\text { Coefficient } \\
\text { (St. error) }\end{array}$ & P-values & Marginal effect \\
\hline Age of shop owner in years & $\begin{array}{c}-0.7610^{* * *} \\
(0.2891)\end{array}$ & 0.0001 & -0.0014 \\
\hline Age of the business in years & $\begin{array}{l}0.0134^{* * *} \\
(0.0050)\end{array}$ & 0.0012 & 0.0024 \\
\hline Knowledge of stock management & $\begin{array}{c}-1.8992^{* * *} \\
(0.7638)\end{array}$ & 0.0034 & 0.4062 \\
\hline Daily sales of the trader & 1.0068 & & \\
\hline Gender of the business operator & $\begin{array}{c}1.3489 \\
(0.7897)\end{array}$ & 1.8927 & 0.0127 \\
\hline Marital status & $\begin{array}{c}-1.2970^{* * *} \\
(0.639)\end{array}$ & 0.0420 & 0.1501 \\
\hline Number of years spent schooling & $\begin{array}{l}0.1015^{* * *} \\
(0.0012)\end{array}$ & 0.0015 & 0.2394 \\
\hline Distance to the nearest supplier office in kilometers & $\begin{array}{c}0.0043 \\
(0.0075)\end{array}$ & 2.0581 & 0.2301 \\
\hline Ability to use ICT to order goods & $\begin{array}{l}2.6781^{* * * *} \\
(0.9245)\end{array}$ & 0.0021 & 0.5100 \\
\hline Size of the business with the net asset in Ghana Cedis & $\begin{array}{c}0.5315 \\
(0.8940)\end{array}$ & 2.3698 & 0.1122 \\
\hline Number of employees & $\begin{array}{c}0.2110 \\
(0.4881)\end{array}$ & 3.2587 & 0.0045 \\
\hline Take records of inflows and outflow of stock & $\begin{array}{c}0.0032^{*} \\
(0.0013)\end{array}$ & 0.0789 & 0.0572 \\
\hline Constant & $\begin{array}{l}-0.3544 \\
(4.0258)\end{array}$ & 1.2458 & - \\
\hline LR Chi-Square (X) & 193.96 & & \\
\hline Pron $>$ Chi-Square & 0.00000 & & \\
\hline Log likelihood & -36.3134457 & & \\
\hline Pseudo R2 & 0.71028 & & \\
\hline
\end{tabular}

${ }^{* * *}$ Significant at 1\%; ${ }^{* *}$ Significant at 5\%; ${ }^{*}$ Significant at 10\%; Source: Field Survey Data 2014.

the data revealed that most of the respondents who are married operate the business with their wives. Based on the result of the marginal effect married retail shop owners are $5 \%$ less likely to experience stock-out.

From the result, education is significant at $1 \%$ significant level and negative. The variable is measured as the total number of years a respondent spend in formal education. The negative coefficient value of the variable means that the more educated retailers are, the less likely they are to experience stock-out. With each additional year of formal education retail shop owners are 34\% less likely to experience stock-out. Similar to this was the findings of Campo et al. [32] who found education to have a negative effect on the probability of SMEs experiencing stock-out.

Respondents who are able to use ICT to order goods have a lower chance of experiencing stock-out as this variable has a negative but significant coefficient with a marginal effect of 0.51012 . This implies that retail shop owners who used ICT to order goods are 51\% less likely to experience stock-out.

The study also revealed that those who keep proper records of their transactions, particularly stock books, are less likely to experience stock-out as the coefficient of this variable is negative and significant at $0 \%$. The marginal effect revealed that retail shop owners who keep stock records are $6 \%$ less likely to experience stock-out.

\subsection{Constraints to Stock Management}

The study identified three main issues that respondent perceived as constraint to stock management. These are inability to forecast demand accurately; inability and lack of use of stock books; and irregular review of stock. The respondents were asked to rank these constraints, and the result of the ranking is presented in Table 4 . The tests of significance in terms of the degree of agreement between the rankings of the constraints to stock management by respondents is above $60 \%$ which is fairly high.

The study revealed that the most important constraint faced by the respondents in management of stock is the 
Table 4. Perceived challenges associated with stock management.

\begin{tabular}{lccc}
\hline \multicolumn{1}{c}{ Influencing factors (Constraints) } & Frequency ${ }^{*}$ & Percentage & Rank \\
\hline Inability to forecast demand accurately & 102 & 21.94 & 3 \\
Inability to use stock books & 214 & 46.02 & 1 \\
Irregular review of stock & 149 & 32.04 & 2 \\
Total & & 100 \\
Coefficient of concordance (W) & & 0.6375 (63.75\%) \\
\hline
\end{tabular}

Source: Field Survey Data 2014. ${ }^{*}$ Multiple response.

inability or lack of use of stock books followed by irregular review of stock while inability of the respondents to forecast demand accurately was ranked third.

\subsection{Conclusions and Recommendations}

The stock-out phenomenon is considered as one of the major problems confronting retailers; and retailers that manage it effectively and efficiently stand to gain a competitive advantage. The occurrence of stock-out reflects all the deficiencies in the supply chain which include incorrect demand forecasting, low replenishment rates, incorrect ordering of products and delays on the part of suppliers [3]. Consistent with Battista et al. [3] the study identifies key determinants of stock-outs. Notably among them are the educational level of the respondents; the ability of the shop owner to use ICT to order stock; age and marital status of the respondents; as well as the gender of the retail shop owner. This finding is consistent with the results of other international studies by Emmelhainz et al. [9], Schary and Martin [33], Nielsen [34], and Corsten and Gruen [8] which pointed to the retailers themselves being responsible for the stock-out problems. This is because it has been observed that personal characteristics of the shop owners significantly influence the probability of them experiencing stock-out. The respondents identified demand underestimation due to poor forecasting, and bad back-of-store practices are the major causes of stock-outs. It can be concluded that, due to lack of warehouses, most of the retailers are not able to adopt appropriate store management practices. Based on the regression result, it can be concluded that using ICT to order goods and keeping of appropriate stock book as well as education on appropriate stock management practices would help reduce stock-out in retail shops.

Beyond the findings from the retailers, the four key conclusions from the research are:

1. Retailers do not have clear insight into issues pertaining to retail logistics and supply systems that are dependent on the use of information technology.

2. Control of data and information coupled with robust logistic system remains the key to availability of products and services.

3. A stock-out situation in a retail shops would be reduced or avoided when retailers form partnerships with logistics providers.

4. Finally a holistic approach in tackling the stock out situations in respect of store forecasting and ordering, replenishment of goods through store stockings and warehousing management; as well as managerial planning would reduce stock out in retail shops.

It is recommended that retailers should take stock frequently and it should be consistent with the market potential and demand as this would not only help them to avoid stock-out but also support them in identifying pilferage of their stock.

Retailers should be educated on retail logistics and supply systems that are dependent on the use of information technology as well as how to keep proper stock books. This would assist them to get goods on time at a cheaper cost and also identify stock which is running out in time to be able to place an order. Retailers should be encouraged to partner logistics providers in areas of information sharing to reduce and possibly avoid stock-out situations. Furthermore, there is the need for a holistic approach in tackling the stock-out situations in respect of store forecasting and warehousing management.

\section{References}

[1] Berman, B. and Evans, J.R. (2007) Retail Management: A Strategic Approach. 10th Edition, Pearson Prentice Hall, 
New Jersey.

[2] Anupindi, R., Dada, M. and Gupta, S. (1998) Estimation of Consumer Demand with Stock-Out Based Substitution: An Application to Vending Machine Products. Marketing Science, 17, 406-423.

[3] Battista, C., Falsini, D., Scarabotti, I. and Schiraldi, M.M. (2011) Quantifying Shelf-out-of-Stock in Fashion \& Apparel Retail Stores. Proceedings of the Conference "Breaking down the Barriers between Research and Industry", Padova, 14-16 September 2011.

[4] Moon, M.A., Mentzer, J.T., Smith, C.D. and Garver, M.S. (1998) Seven Keys to Better Forecasting. Business Horizons, 41, 44-52.

[5] Vasconcellos, L.H.R. and Sampaio, M. (2009) The Stockouts Study: An Examination of the Extent and the Causes in the Sao Parlo Supermarket Sector. Brazilian Administration Review, 6, 263-279.

[6] Peckham, J. (1963) The Consumer Speaks. Journal of Marketing, 27, 21-26.

[7] Gruen, T.W. and Corsten, D. (2008) A Comprehensive Guide to Retail out of Stock Reduction in the Fast-Moving Consumer Goods Industry. Grocery Manufacturers of America, Washington DC.

[8] Andersen Consulting (1996) Where to Look for Incremental Sales: The Retail Problem of Stockout Merchandise. The Coca Cola Research Council, Atlanta.

[9] Emmelhainz, M., Emmelhainz, L. and Stock, J. (1991) Consumer Responses to Retail Stock Outs. Journal of Retailing, 22, 50-71.

[10] Elgar, F. and Tellkamp, C. (2005) Inventory Inaccuracy and Supply Chain Performance: A Simulation Study of a Retail Supply Chain. International Journal of Production Economics, 95, 273-385.

[11] Anderson, E.T., Fitzsimons, G.J. and Simester, D. (2006) Measuring and Mitigating the Costs of Stockouts. Management Science, 52, 1751-1763. http://dx.doi.org/10.1287/mnsc.1060.0577

[12] Bhargava, H.K., Sun, D. and Xu, S.H. (2006) Stockout Compensation: Joint Inventory and Price Optimization in Electronic Retailing. Journal on Computing, 18, 255-266.

[13] Gruen, T.W. and Corsten, D. (2007) A Comprehensive Guide to Retail Out-of-Stock Reduction in the Fast-Moving Consumer Goods Industry. The University of Colorado and the IE Business School Madrid.

[14] Balachander, S. and Farquhar, P.H. (1994) Gaining More by Stocking Less: A Competitive Analysis of Product Availability. Marketing Science, 13, 3-22. http://dx.doi.org/10.1287/mksc.13.1.3

[15] Toomey, J.W. (2000) Inventory Management: Principles, Concepts and Techniques. Kluwer Academic Publishers, Norwell. http://dx.doi.org/10.1007/978-1-4615-4363-3

[16] Muller, M. (2003) Essentials of Inventory Management. AMACOM, New York.

[17] Wild, T. (2002) Best Practice in Inventory Management. 2nd Edition, Butterworth Heinemann., Oxford.

[18] Ehrenthal, J.C.F., Gruen, T.W. and Hofstetter, J.S. (2014) Value-Attenuation and Retail Out-of-Stocks: A ServiceDominant Logic Perspective. International Journal of Physical Distribution \& Logistics Management, 44, 32-57.

[19] Gruen, T.W., Corsten, D. and Bharadwaj, S. (2002) Retail Out-of-Stocks: A Worldwide Examination of Causes, Rates, and Consumer Responses. Grocery Manufacturers of America, Washington DC.

[20] Berger, R. (2003) Optimal Shelf Availability-Increasing Shopper Satisfaction at the Moment of Truth. Roland Berger Consultants, Kontich, 10-23.

[21] Zinn, W. and Liu, P.C. (2001) Consumer Response to Retail Stockouts. Journal of Business Logistics, 22, 49-71. http://dx.doi.org/10.1002/j.2158-1592.2001.tb00159.x

[22] Aastrup, J. and Kotzab, H. (2010) Forty Years of Out-of-Stock Research-And Shelves Are Still Empty. International Review of Retail, Distribution \& Consumer Research, 20, 147-164. http://dx.doi.org/10.1080/09593960903498284

[23] Coyle, J.J., Bardi, E.J. and Langley Jr., C.J. (2003) The Management of Business Logistic: A Supply Chain Perspective. 7th Edition, South-Western, Mason.

[24] Krafft, M. and Mantrala, M.K. (2010) Retailing in the 21st Century. 2nd Edition, Springer, Berlin. http://dx.doi.org/10.1007/978-3-540-72003-4

[25] Sloot, L.M., Verhoef, P.C. and Frances, P.H. (2005) The Impact of Brand Equity and the Hedonic Level of Products on Consumer on Consumer Stock-Out Reactions. Journal of Retailing, 81, 15-34. http://dx.doi.org/10.1016/j.jretai.2005.01.001

[26] Yamane, T. (1967) Statistics: An Introductory Analysis. 2nd Edition, Harper and Row, New York.

[27] Frankfort-Nachmias, C. and Nachmias, D. (1996) Research Methods in the Social Sciences. St. Martin’s Press, New York.

[28] Pindyck, S.R. and Rubinfeld, L.D. (1998) Econometric Models and Economic Forecasts. Irwin/McGraw-Hill, New 
York.

[29] Fitzsimons, G.J. (2000) Consumer Response to Stocks. Journal of Consumer Research, 27, 249-266. http://dx.doi.org/10.1086/314323

[30] Christopher, M. (2011) Logistics and Supply Chain Management. 4th Edition, FT Prentice Hall, Harlow.

[31] Campo, K., Gijbrechts, E. and van Nisol, P. (2003) The Impact of Retailer Stockouts on Whether, How Much, and What to Buy. International Journal of Research in Marketing, 20, 273-286. http://dx.doi.org/10.1016/S0167-8116(03)00037-5

[32] Campo, K., Gijbrechts, E. and van Nisol, P. (2004) Dynamics in Consumer Response to Product Unavailability: Do Stock-Out Reactions Signal Response to Permanent Assortment Reductions? International Journal of Business Research, 57, 834-843.

[33] Schary, P.B. and Martin, C. (1979) The Anatomy of a Stock-out. Journal of Retailing, 55, 59-70.

[34] Zinn, W. and Liu, P.C. (2008) A Comparison of Actual and Intended Consumer Behavior in Response to Retail Stockouts. Journal of Business Logistics, 29, 141-159. http://dx.doi.org/10.1002/j.2158-1592.2008.tb00090.x 
Scientific Research Publishing (SCIRP) is one of the largest Open Access journal publishers. It is currently publishing more than 200 open access, online, peer-reviewed journals covering a wide range of academic disciplines. SCIRP serves the worldwide academic communities and contributes to the progress and application of science with its publication.

Other selected journals from SCIRP are listed as below. Submit your manuscript to us via either submit@scirp.org or Online Submission Portal.
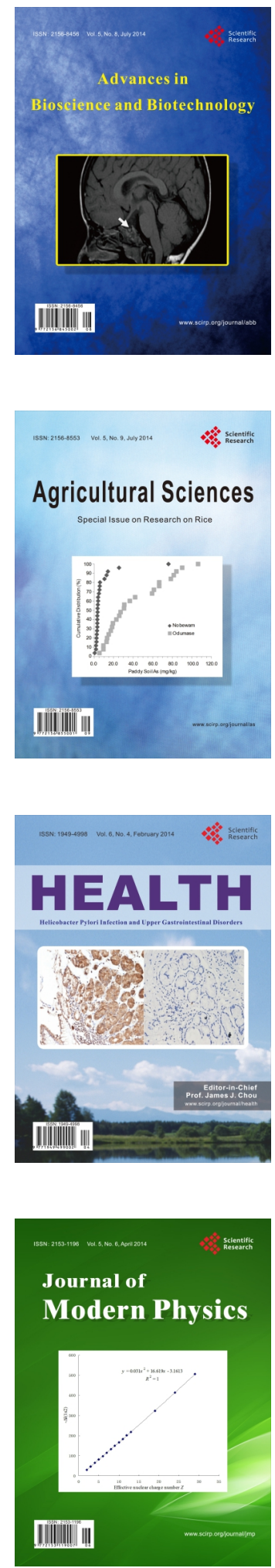
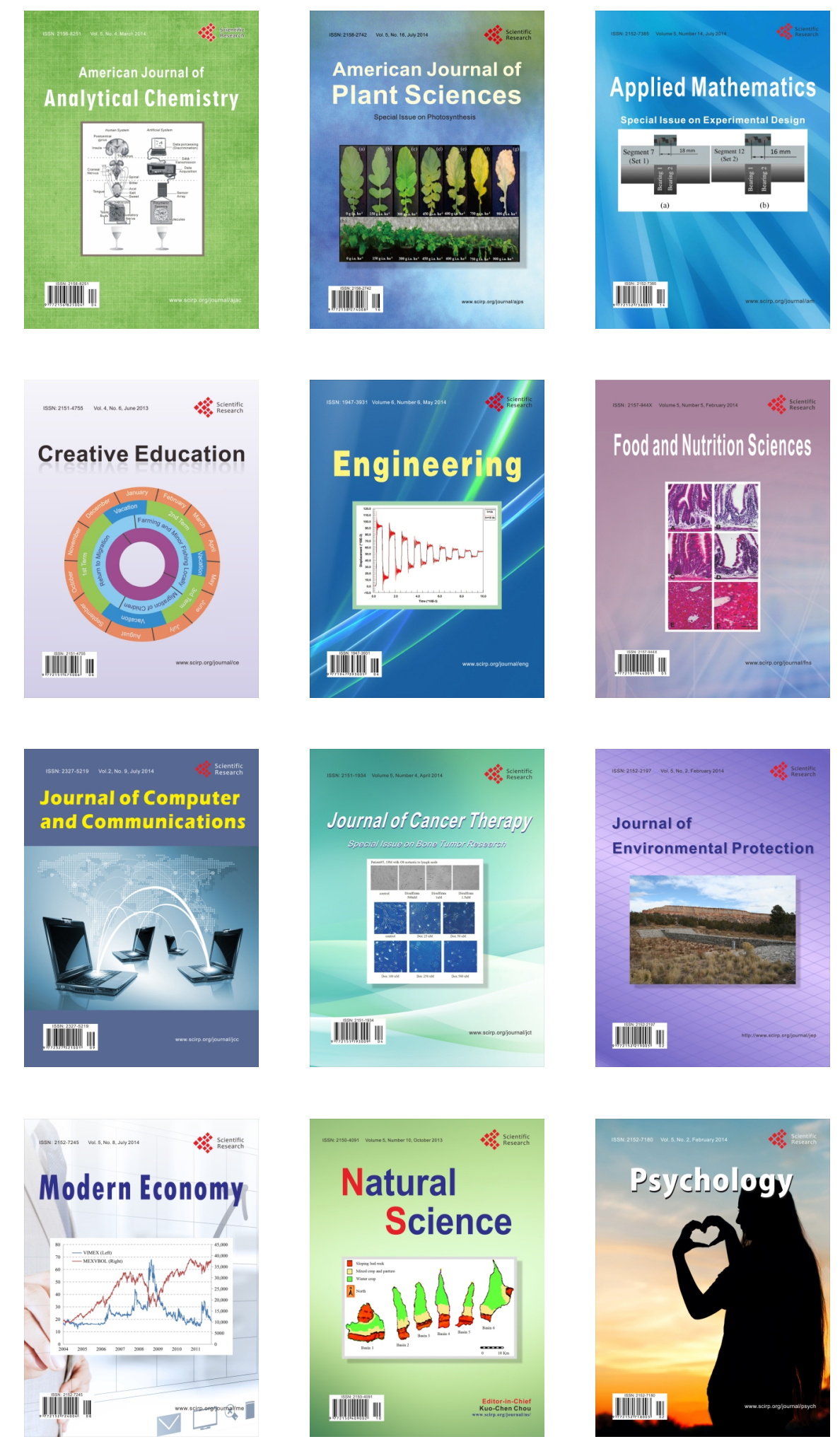